\title{
A Brief Talk on the Alienation of Human Nature - from A Curtain of Green and Other Stories
}

\author{
Hu Song \\ School of foreign languages, Dalian Jiaotong University, Dalian Liaoning, 116021, China
}

Keywords: Eudora Welty; Marx; alienation of human nature

\begin{abstract}
In this paper, I will base my argument on the theory of alienation which is one of the most important theories in Marxism. Through the analysis of Eudora Welty's first short stories A Curtain of Green and Other Stories, through the exploration of the cause and the embodiments of the alienation of human nature, we can conclude that ordinary people can reach their self-redemptions on their way of overcoming the alienation of human nature .
\end{abstract}

\section{Preface}

The south of America gained its nickname of "cultural desert" by many scholars. After Word War I, a great number of outstanding writers, dramatists, poets, literary critics and theoretical scholars rapidly emerged in this region. It is termed as "Southern Renaissance". Undoubtedly, Eudora Welty is one of the most remarkable writers at that time.

Born in the early $20^{\text {th }}$ century, Eudora Welty began to publish her papers on some children's magazines since secondary school. In 1936, her first short story - Death of a Traveling Salesman was published, letting the whole literary circle of America to know Welty. In 1941, her collection of short stories - A Curtain of Green \& Other Stories got published, letting the world to know Welty. With her unique writing techniques, recounting measures, vivid language and detailed description, Eudora Welty conquers the world. She is honored as an excellent successor of Faulkner. During her lifetime, Eudora Welty won many prizes. Moreover, she becomes the first person in the world whose literary works are selected into the "Library of America" when she is alive.

In total, 17 short stories are collected in A Curtain of Green \& Other Stories. From small figures and things in such stories, we see the most genuine side of southern America just in economic system reform. The conservative South after World War I began to suffer from strong impact from capitalism in the North. Sudden change in economic system not only reforms long-term stagnant economy of the South but also alienates conservative character of southern people.

\section{Reasons for Alienation of Human Nature}

During her lifetime, Welty hardly left her hometown - a poor small town in the South, i.e. Jackson in the middle of Mississippi. Regional limitation never restrains Welty's literary creation. On the contrary, Welty is made to deeply explore for people living at the rock-bottom due to her familiarity with native land as well as people and things around. In the transformation period of society, she went through the loss of life, loneliness, hesitation, hopelessness and alienation of human nature.

Since the birth of mankind, humans work extremely hard and bitter for the sake of survival and development, and continuously pursue for freedom and liberation. However, humans fail to realize complete freedom and libration due to complexity of the objective world and various limitations of human beings. "Under the force of alienation, human beings gradually lose ego and nature as well as subjectivity, spiritual freedom and personality. Humans become non-humans, with personality trending to be disintegrated [1]". This is so-called alienation theory.

As an important method of literary criticism, the central content of alienation theory lies on discussion of and exploration for alienation of human nature. Over the years, many scholars have carefully reflected on reasons for alienation of human nature. However, Marxian analysis on alienation of human nature is undoubtedly the most profound and the most influential. 
Marx inherited critically Hegelian spiritual alienation theory and Feuerbach's religious alienation theory, and endowed deeper realistic meaning to alienation of human nature - review for roots of alienation of human nature from the perspectives of real life and economic structure reform in human society. Marx pointed in Marx's Economics Philosophy Manuscript in 1884 that "alienation of human nature is mainly sourced from the private ownership of capitalism”. According to Marx, it is just the appearance of capitalist private ownership that causes alienation of social labor and productive labor products produced by human beings in the creating process of a new world. As a result, humans, as subjects of labor, are led to "deny them instead of affirming themselves and feel unfortunate instead of happiness in the process of self labor, and make their bodies and spirits to be tortured instead of giving play to their physical strength and intelligence [2]". With continuous development of capitalist system highly worshipping material civilization, the alienation degree of human nature becomes deeper and deeper.

\section{Presentation to Alienation of Human Nature}

The South of America after World War I is just in a turbulent period of social, political and economic system. Capitalist economic form overturns people's traditional lifestyles and survival values. To rapidly amass social wealth by heavy taxation, emerging bourgeoisies roughly exploit and plunder. So-called democracy is only for a few people. All legal institutions also become means and tools for the ruling class to amass wealth. Social contradictions are increasingly intensified. Literature is the optimum pattern to reflect social and real life. Living in such period, Welty deeply experienced disasters brought by industrial civilization of capitalism and cruel war. From her works, we can see painful struggle and twisted nature of people living at the bottom of the southern society in America.

In the Death of a Traveling Salesman, the protagonist Bowman is one of extremely typical representatives. In the past 14 years, Bowman was worked as a salesman in a shoe factory. He was busy running about throughout the year. However, he failed to have a steady and peaceful life. On the contrary, he became a numb and cold-blooded selling machine. He had no friend or relative, or a family. Even through he was sick, he had to overlie in the bed and recall his grandma who already passed away, imagining that he was lying in the big bed made by his grandma. Besides, he thought that he could exchange money for transitory care from the nurse. In his opinion, there was no true love or family affection between people. Instead, there was only the relationship between buying and selling as well as transaction of money and object. Such lonely and indifferent character makes him not to easily believe in anyone. More seriously, he even showed no care or sympathy to those persons as hardworking as him. On the contrary, he was full of contempt. When he got lost on the road, he was reluctant to ask the way toward strangers [3]188, and thought that "although these persons are living roadside, they don't know the direction the road leads to [3]188”. When his car slipped into mountain stream, he had to ask poor Mr. and Mrs. Sony for help, and attempted to exchange money for the couple' help. Although the couple was as poor as a church, they helped strangers like Bowman, without asking for return. Although they were good at talking, they lived in mutual love, and raised a baby symbolizing future and hope. All these things gave a great blow to Bowman. Hard working in the past 14 years only brings about material satisfaction to Bowman. Spiritual emptiness finally pushes him to death.

If lonely Bowman is touching, then Howard in the Flower to Marjoeli is more worthy of our sympathy. Howard was unemployed for a long period. However, his wide was about to give birth to a baby. To support his family, Howard had to give up his dignity as a man and humbly fawn upon Ms. Fergusson, so as to be given with a job opportunity, even if it was only to pave the road. However, he would receive sarcastic comments and scornful supercilious look every time. He had no choice but to wander around. Huge life pressure made Howard almost to be in a collapse. Although Howard abided by the law and behaved himself all the time, he still could not make a living. Although he loved his wife Marjoeli very much, he killed his wife in a trance. Rapidly developed capitalist industrial civilization failed to make poor people like Howard to get rid of poverty and unemployment. On the contrary, they were made to be in a worse state, letting them to 
be stricken by both flesh and spirit. Finally, that leads to overall alienation of human nature.

\section{Approaches for Overcoming Alienation of Human Nature}

Marx ever said that "alienation of human nature is an inevitable product of human development. Overcoming of alienation is also inevitable for human development [4]”. Although it is impossible for people to decide their social class and social status, humans, as founders of the whole world, will finally select their destinies with their own methods, and find out ways to get rid of difficulties.

A Worn Path presents an image of a weather-beaten black old woman who still moves ahead. To let sick grandson to regain the hope of survival, Phoenix, with an indomitable will, overcomes various difficulties in the road to ask for medicine in the city: all kinds of wild animals, mosquitoes and other insects, bushes with thistles and thorns, fences with steel wires, white hunter and his big black dog. In face of natural barriers and various obstructs set by the white to the black, this old woman already moves ahead on the road to freedom and fairness.

Do you still remember that couple who selflessly helped Bowman in the Death of a Traveling Salesman? They live in a simple house, wear rags made of coarse cloth and eat simple dishes. However, they are happy and harmonious. They cut off various thistles and thorns in real life with their ways, and inject new vitality to the completely business-like era with trust and care to each other, letting hardworking persons to see values of survival and thus pick up the courage to move ahead again.

With her "exquisite pen, vivid pen and plain pen [5]", Welty finds the spiritual homeland for those people living in the period of Great Depression. They are in adverse situation, but they are still full of love and strong will, supporting them to move ahead and relieve the most precious rays of light in human nature.

\section{Conclusion}

Marx ascended the root of alienation of human nature to the level of economy and politics. Besides, he highly summarized the fact that people losing freedom in the society with private ownership will finally lead to alienation of human nature in the face of the alienated world. However, they can still overcome and conquer all difficulties, and strive for a brilliant future by virtue of their strength. Marx ever said that “alienation of human nature doesn't mean degeneration of human nature. The process of overcoming alienation of human nature also means the development of human history. Moreover, it is of progressive significance in the human history". Welty, this excellent "white southern female still makes up her mind to stride across the borders full of hostility, and to explore for alienated souls with her imaginative brushworks. In her works, pleasure, anger, sorrow and joy of all living things affect the heart of each reader, communicating isolated souls in modern society [6]”.

\section{References}

[1] Jiang Chengyong, Freedom, Alienation and Literature [J], Foreign Literature Studies, 1994 (2): p36;

[2] Marx’s Economics Philosophy Manuscript in 1884, Liu Pikun, People’s Publishing House, 1979, p51;

[3] Eudora Welty. A Curtain of Green and Other Stories (M). Orlando: Harcourt Brace Jovanovich, Publishers, 1979.

[4] Marx and Engels, Volume I of Discussion on Arts by Marx and Engels, Beijing: China Social Sciences Publishing House, 1983, p313;

[5] Lu Ruirong and Liu Caixia, Comedy and Tragedy of Small Potatoes [J], Journal of Gannan Teachers' College, 2005 (4): p59;

[6] Mao Li, Multiple Variations of Alienated Souls - collected excellent papers (Volume II) of the $2^{\text {nd }}$ Social Science Academic Annual Conference of Heilongjiang Province, Heilongjiang University Press, 2011: p707;

[7] Xiao Minghan, The Sense of Dissimilation and Conservatism in Literature [J], Foreign Literature Review, 1994 (1): p64-71;

[8] Gao Lin, Review for Alienation Theory in Mainstream of Western Aesthetics [J], Journal of Liuzhou Teachers College, 2009 (5): p20-23. 